SGW-34562

Revision 0

\title{
Alternative Remediation Technology Study for Groundwater Treatment at 200-PO-1 Operable Unit at Hanford Site
}

Prepared for the U.S. Department of Energy

Assistant Secretary for Environmental Management

Project Hanford Management Contractor for the

U.S. Department of Energy under Contract DE-AC06-96RL13200

FLUOR.

P.O. Box 1000

Richland, Washington 


\section{Alternative Remediation Technology Study for Groundwater Treatment at 200-PO-1 Operable Unit at Hanford Site}

Document Type: RPT

Program/Project: S\&GRP

M. A. Dado

Cl Intern/Fluor Hanford, Inc.

Date Published

August 2008

Prepared for the U.S. Department of Energy

Assistant Secretary for Environmental Management

Project Hanford Management Contractor for the

U.S. Department of Energy under Contract DE-AC06-96RL13200

\section{FLUOR。}

P.O. Box 1000

Richland, Washington

A.8. Aasalal $\frac{07 / 31 / 2008}{\text { Rate }}$ 
SGW-34562

Revision 0

TRADEMARK DISCLAIMER

Reference herein to any specific commercial product, process, or service by trade name, trademark, manufacturer, or

otherwise, does not necessarily constitute or imply its

endorsement, recommendation, or favoring by the United

States Government or any agency thereof or its contractors or subcontractors.

This report has been reproduced from the best available copy. 
SGW-34562 REV 0

This page intentionally left blank. 


\section{EXECUTIVE SUMMARY}

This study focuses on the remediation methods and technologies applicable for use at 200-PO-1 Groundwater Operable Unit (OU) at the Hanford Site. The 200-PO-1 Groundwater OU requires groundwater remediation because of the existence of contaminants of potential concern (COPC). A screening was conducted on alternative technologies and methods of remediation to determine which show the most potential for remediation of groundwater contaminants. The possible technologies were screened to determine which would be suggested for further study and which were not applicable for groundwater remediation. COPCs determined by the Hanford Site groundwater monitoring were grouped into categories based on properties linking them by remediation methods applicable to each COPC group.

The screening considered the following criteria.

1. Determine if the suggested method or technology can be used for the specific contaminants found in groundwater and if the technology can be applied at the 200-PO-1 Groundwater OU, based on physical characteristics such as geology and depth to groundwater.

2. Evaluate screened technologies based on testing and development stages, effectiveness, implementability, cost, and time.

This report documents the results of an intern research project conducted by Mathew Dado for Central Plateau Remediation in the Soil and Groundwater Remediation Project. The study was conducted under the technical supervision of Gloria Cummins and management supervision of Theresa Bergman and Becky Austin. 
SGW-34562 REV 0

This page intentionally left blank. 
SGW-34562 REV 0

\section{CONTENTS}

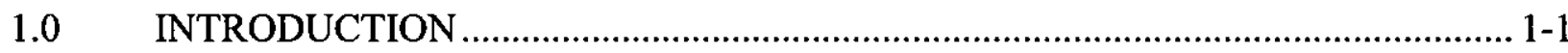

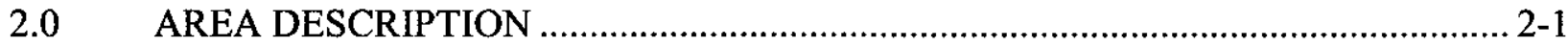

3.0 FIRST STEP: TECHNOLOGIES NO LONGER CONSIDERED BASED ON PHYSICAL LIMITATIONS ............................................................................ 3-1

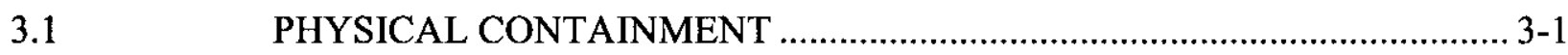

3.2 REMOVAL, TREATMENT, AND DISPOSAL …………........................ 3-1

4.0 SECOND STEP: EVALUATION OF TECHNOLOGIES ....................................... 4-1

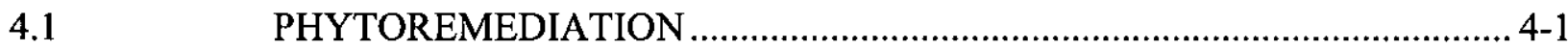

4.1.1 Enhanced Rhizosphere Biodegradation .......................................... 4-1

4.1.2 Hydraulic Control......................................................................... 4-2

4.1.3 Phyto-Degradation ....................................................................... 4-2

4.1.4 Phyto-Volatilization ................................................................... 4-2

4.1.5 Phytoremediation Studies ........................................................... 4-2

4.2 PERMEABLE REACTIVE BARRIERS …………………......................... 4-3

4.3 MONITORED NATURAL ATTENUATION ........................................ 4-4

$4.4 \quad$ PUMP AND TREAT ...............................................................................

4.5 CHEMICAL STABILIZATION BY INJECTABLE APATITE ...................... 4-7

4.6 CHEMICAL STABILIZATION BY POLYPHOSPHATE ............................... 4-7

4.7 DOWN-WELL BIOREACTOR SYSTEM .......................................... 4-8

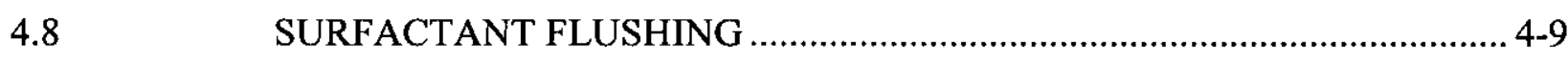

4.9 ANAEROBIC BIOREMEDIATION ……........................................... 4-10

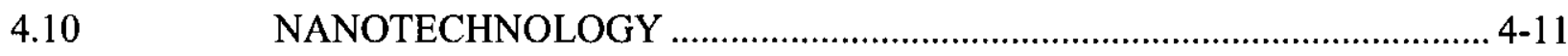

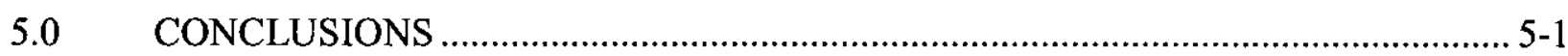

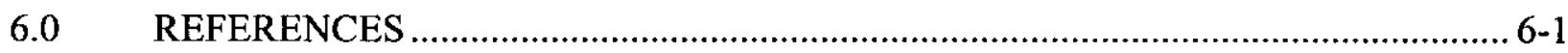

\section{FIGURES}

Figure 1-1. 200-PO-1 Groundwater Operable Unit Showing Monitoring Wells. ...................... 1-2

Figure 1-2. Radionuclide Contamination in Groundwater at the Hanford Site......................... 1-3

Figure 2-1. Operable Units at Hanford Site and Far Field of the 200-PO-1 Groundwater Operable Unit.

Figure 2-2. Near Field of the 200-PO-1 Groundwater Operable Unit........................................ 2-3 


\section{TABLES}

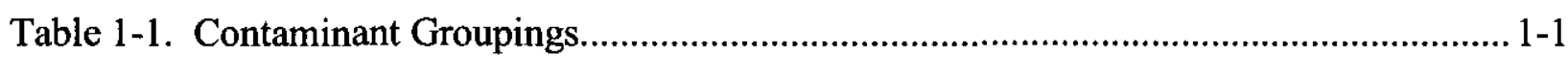

Table 1-2. Potential Technologies for all Contaminant of Potential Concern Groups............... 1-4

Table 3-1. Technologies Screened out in Initial Screening. ..................................................... 3-2

Table 4-1. Evaluation Criteria Used in Second Step of Screening............................................ 4-1

Table 4-2. Phytoremediation......................................................................................... 4-3

Table 4-3. Permeable Reactive Barriers. (2 Pages) ................................................................ 4-4

Table 4-4. Monitored Natural Attenuation. .......................................................................... 4-5

Table 4-5. Pump and Treat.......................................................................................... 4-6

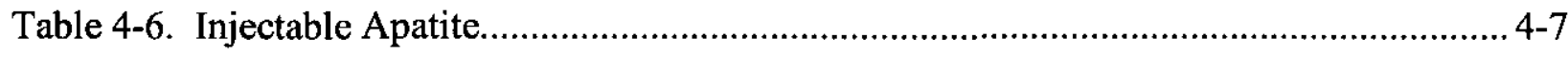

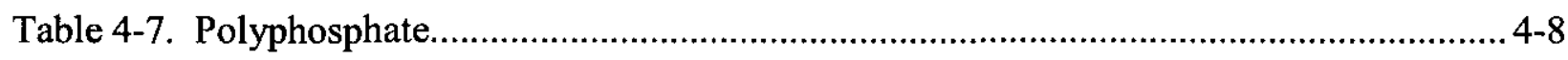

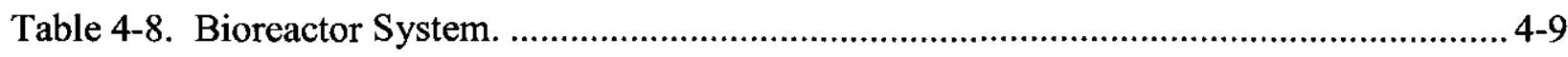

Table 4-9. Surfactant Flushing.................................................................................. 4-10

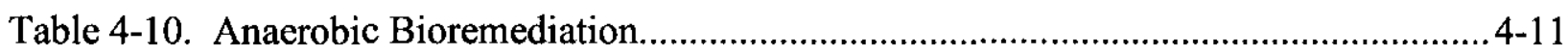

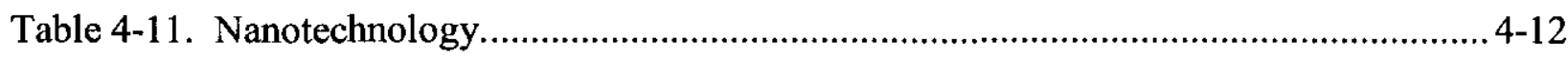

Table 5-1. Summary of Technologies Suggested for Further Consideration. ........................... 5-1

Table 5-2. Summary of Current Implementability of Technologies............................................ 5-2 
SGW-34562 REV 0

\section{TERMS}

COPC

DNAPL

EPA

ISRM

MNA

NAPL

OU

PRB contaminant of potential concern

dense, nonaqueous-phase liquid

U.S. Environmental Protection Agency

in situ redox manipulation

monitored natural attenuation

nonaqueous-phase liquid

operable unit

permeable reactive barrier 


\section{METRIC CONVERSION CHART}

Into Metric Units

\begin{tabular}{|c|c|c|c|c|c|}
\hline If you know & Multiply by & To get & If you know & Multiply by & To get \\
\hline \multicolumn{3}{|l|}{ Length } & \multicolumn{3}{|l|}{ Length } \\
\hline inches & 25.40 & millimeters & millimeters & 0.0394 & inches \\
\hline inches & 2.54 & centimeters & centimeters & 0.394 & inches \\
\hline feet & 0.305 & meters & meters & 3.281 & feet \\
\hline yards & 0.914 & meters & meters & 1.094 & yards \\
\hline miles (statute) & 1.609 & kilometers & kilometers & 0.621 & miles (statute) \\
\hline \multicolumn{3}{|l|}{ Area } & \multicolumn{3}{|l|}{ Area } \\
\hline sq. inches & 6.452 & sq. centimeters & sq. centimeters & 0.155 & sq. inches \\
\hline sq. feet & 0.0929 & sq. meters & sq. meters & 10.764 & sq. feet \\
\hline sq. yards & 0.836 & sq. meters & sq. meters & 1.196 & sq. yards \\
\hline sq. miles & 2.591 & sq. kilometers & sq. kilometers & 0.386 & sq. miles \\
\hline acres & 0.405 & hectares & hectares & 2.471 & acres \\
\hline \multicolumn{3}{|l|}{ Mass (weight) } & \multicolumn{3}{|l|}{ Mass (weight) } \\
\hline ounces (avoir) & 28.349 & grams & grams & 0.0353 & ounces (avoir) \\
\hline pounds & 0.454 & kilograms & kilograms & 2.205 & pounds (avoir) \\
\hline tons (short) & 0.907 & ton (metric) & ton (metric) & 1.102 & tons (short) \\
\hline \multicolumn{3}{|l|}{ Volume } & \multicolumn{3}{|l|}{ Volume } \\
\hline teaspoons & 5 & milliliters & milliliters & 0.034 & $\begin{array}{l}\text { ounces } \\
\text { (U.S., liquid) }\end{array}$ \\
\hline tablespoons & 15 & milliliters & liters & 2.113 & pints \\
\hline $\begin{array}{l}\text { ounces } \\
\text { (U.S., liquid) }\end{array}$ & 29.573 & milliliters & liters & 1.057 & $\begin{array}{l}\text { quarts } \\
\text { (U.S., liquid) }\end{array}$ \\
\hline cups & 0.24 & liters & liters & 0.264 & $\begin{array}{l}\text { gallons } \\
\text { (U.S., liquid) }\end{array}$ \\
\hline pints & 0.473 & liters & cubic meters & 35.315 & cubic feet \\
\hline $\begin{array}{l}\text { quarts } \\
\text { (U.S., liquid) }\end{array}$ & 0.946 & liters & cubic meters & 1.308 & cubic yards \\
\hline $\begin{array}{l}\text { gallons } \\
\text { (U.S., liquid) }\end{array}$ & 3.785 & liters & & & \\
\hline cubic feet & 0.0283 & cubic meters & & & \\
\hline cubic yards & 0.764 & cubic meters & & & \\
\hline \multicolumn{3}{|l|}{ Temperature } & \multicolumn{3}{|l|}{ Temperature } \\
\hline Fahrenheit & $\left({ }^{\circ} \mathrm{F}-32\right)^{*} 5 / 9$ & Centigrade & Centigrade & $\left({ }^{\circ} \mathrm{C}^{*} 9 / 5\right)+32$ & Fahrenheit \\
\hline \multicolumn{3}{|l|}{ Radioactivity } & \multicolumn{3}{|l|}{ Radioactivity } \\
\hline picocurie & 37 & millibecquerel & millibecquerel & 0.027 & picocurie \\
\hline
\end{tabular}




\section{SGW-34562 REV 0}

\subsection{INTRODUCTION}

To begin this study, technologies applicable to cleanup of the contaminants of potential concern (COPC) at the 200-PO-1 Groundwater Operable Unit (OU) were considered. Considered technologies included those already in use, currently being tested, or being researched. The list of potential technologies is based on information from PNNL-15954, Screening of Potential Remediation Methods for the 200-ZP-1 Operable Unit at the Hanford Site. FRTR, 2002, Remediation Technologies Screening Matrix and Reference Guide, Version 4.0 (a website dedicated to building a collaborative atmosphere for federal agencies involved in hazardous waste cleanup) and EPA, 2008, Hazardous Waste Clean-Up Information (CLU-IN) (a website forum for information about innovative treatment and site characterization technologies for remediation) were used. This study focuses on technologies and methods involved in the remediation of groundwater contamination.

Much of the study is structured like the screening conducted for the 200-ZP-1 Groundwater OU (PNNL-15954), because of the physical similarities between the two units. The 200-ZP-1 Groundwater OU is located in the 200 West Area of the Hanford Central Plateau and the 200-PO-1 Groundwater OU is located in the 200 East Area. The similarities exist in the climate and groundwater depth. Both OUs are in an arid climate and have depth to groundwater

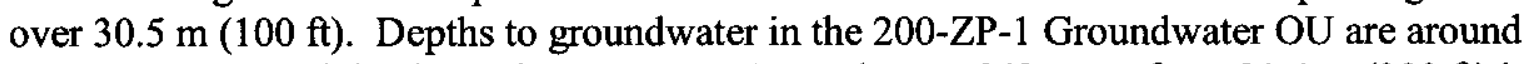

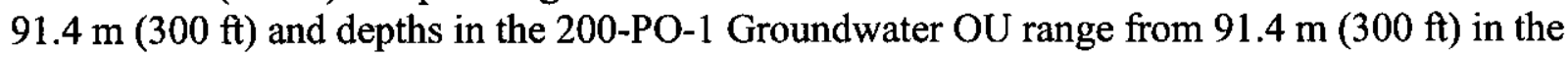

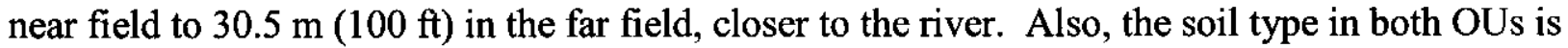
unconsolidated sands and gravels. Based on these similarities, technologies applicable to the 200-ZP-1 Groundwater OU soil or groundwater are assumed to be applicable to the 200-PO-1 Groundwater OU soil or groundwater.

This study determines methods and technologies for remediation based on the type of contaminant. The contaminants are separated into three groups. Group 1 includes I-129, Tc-99, Sr-90, chromium, uranium and cesium. Nitrate is the COPC for Group 2 and tritium is the COPC for Group 3. Group 1 contaminants are grouped based on chemical properties that allow them to be remediated using the same technology. Group 1 contaminants are either radionuclides or heavy metals. Group 2 and Group 3 are separate because nitrate and tritium have unique properties that require different remediation technologies. Table 1-1 lists the contaminant groupings.

Table 1-1. Contaminant Groupings.

\begin{tabular}{|c|c|}
\hline Contaminant Group & Contaminant \\
\hline Group 1 & Iodine-129, Technetium-99, Strontium-90, Chromium, Uranium, Cesium \\
\hline Group 2 & Nitrate \\
\hline Group 3 & Tritium \\
\hline
\end{tabular}

Another COPC considered in this study is non-aqueous phase liquids (NAPL) or dense, nonaqueous phase liquids (DNAPL). Currently, no technologies exist for definitive remediation of DNAPLs (EPA, 1993, Guidance for Evaluating the Technical Impracticability of Ground-Water Restoration). Many compounds are classified as DNAPLs, such as polychlorinated byphenyls, trichloroethylene, and tetrachloroethylene. These liquids exist in water and are denser than water. Technologies to remediate DNAPLs are currently being studied because of their potential existence at 200-PO-1 Groundwater OU. 
The contaminants at the Hanford Site have been monitored over time. Contaminant plumes are areas where contaminated soil or groundwater exists because of liquid waste introduced to the soil or movement of waste constituents through the vadose zone or groundwater. Figures 1-1 and 1-2 present known contaminant plumes.

Figure 1-1. 200-PO-1 Groundwater Operable Unit Showing Monitoring Wells.

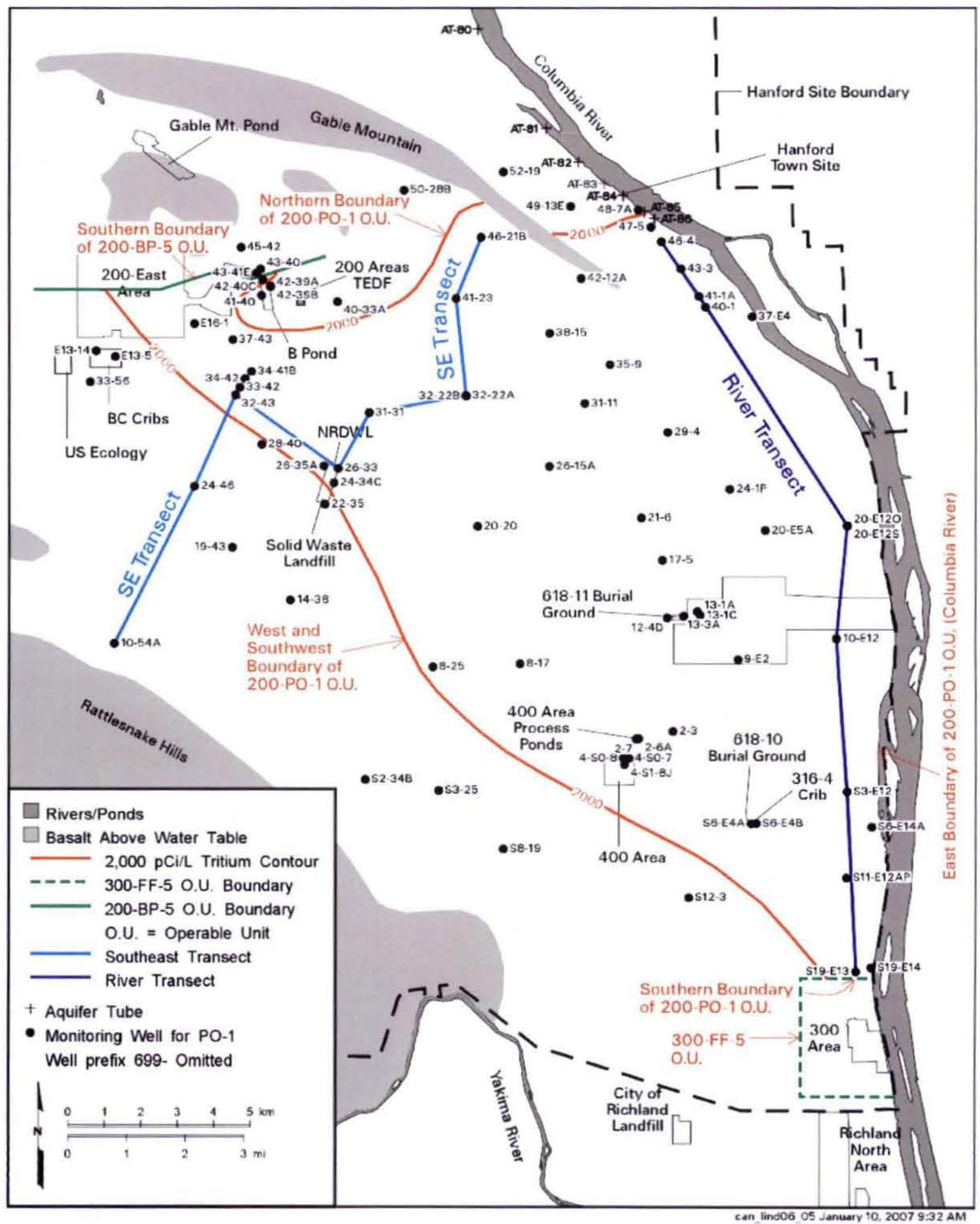

After PNNL-16346, Hanford Site Groundwater Monitoring for Fiscal Year 2006. 


\section{SGW-34562 REV 0}

Figure 1-2. Radionuclide Contamination in Groundwater at the Hanford Site.

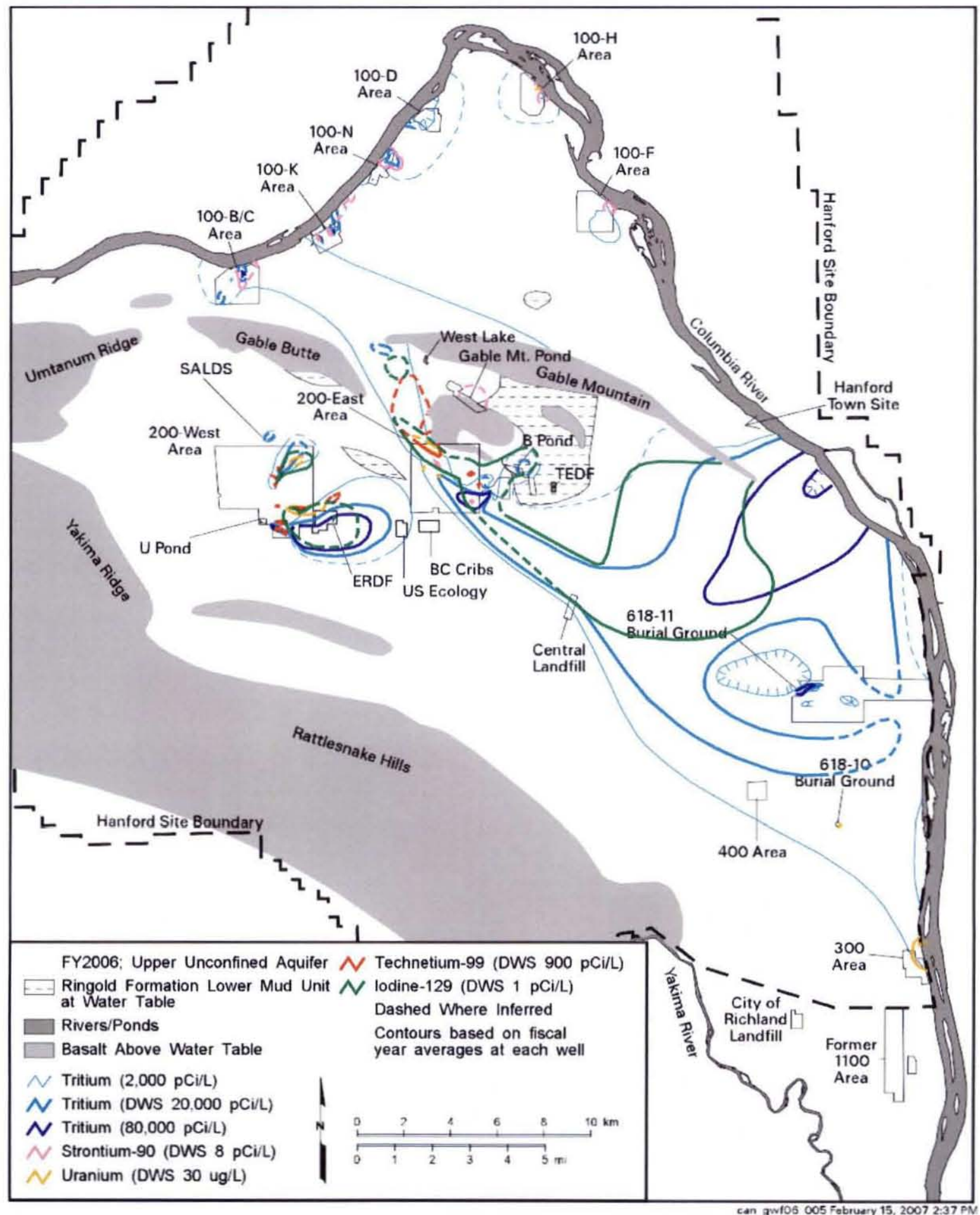

After PNNL-16346, Hanford Site Groundwater Monitoring for Fiscal Year 2006. 
The study began with a list of possible remediation technologies listed by each COPC group.

The initial screening included all technologies and the results are presented in Chapter 3.0.

Table 1-2 details the original list of technologies.

Table 1-2. Potential Technologies for Contaminant of Potential Concern Groups.

\begin{tabular}{|c|c|c|}
\hline Group & Category & Remediation Method/Technology \\
\hline \multirow{13}{*}{ Group 1} & Physical Containment & Slurry Walls, Grout Curtain, Sheet Piling \\
\hline & Removal, Treatment, and Disposal & Excavation \\
\hline & Monitored Natural Attenuation & Monitored Natural Attenuation \\
\hline & Ex Situ Treatment & Pump and Treat (Chemical or Biological Treatment) \\
\hline & \multirow{9}{*}{ In Situ Treatment } & Chemical Stabilization by Apatite \\
\hline & & Chemical Stabilization by Polyphosphate \\
\hline & & Nanotechnology (Zero-Valent Iron) \\
\hline & & Down-Well Bio-Reactor/Adsorption Systems \\
\hline & & Surfactant Flushing \\
\hline & & $\begin{array}{l}\text { Phytoremediation (Enhanced Rhizosphere Biodegradation, } \\
\text { Hydraulic Control, Phyto-degradation Volatilization) }\end{array}$ \\
\hline & & $\begin{array}{l}\text { Anaerobic Bioremediation (Soluble substrate or long-duration } \\
\text { substrate) }\end{array}$ \\
\hline & & Permeable Reactive Barriers (Zero-Valent Iron) \\
\hline & & Slurry Walls, Grout Curtain, Sheet Piling \\
\hline \multirow{8}{*}{ Group 2} & Physical Containment & Excavation \\
\hline & Removal, Treatment, and Disposal & Monitored Natural Attenuation \\
\hline & Monitored Natural Attenuation & $\begin{array}{l}\text { Pump and Treat (Chemical, Biological, or Constructed } \\
\text { Wetlands/Phyto-Irrigation) }\end{array}$ \\
\hline & Ex Situ Treatment & Phytoremediation \\
\hline & \multirow{4}{*}{ In Situ Treatment } & $\begin{array}{l}\text { Anaerobic Remediation (Soluble substrate or long-duration } \\
\text { substrate) }\end{array}$ \\
\hline & & Permeable Reactive Barriers \\
\hline & & Slurry Walls, Grout Curtain, Sheet Piling \\
\hline & & Nanotechnology (Zero-Valent Iron) \\
\hline \multirow{8}{*}{ Group 3} & Physical Containment & Excavation \\
\hline & Removal, Treatment, and Disposal & Monitored Natural Attenuation \\
\hline & Monitored Natural Attenuation & Pump and Treat - Isotopic separation \\
\hline & Ex Situ Treatment & Surfactant Flushing \\
\hline & \multirow{4}{*}{ In Situ Treatment } & Permeable Reactive Barriers \\
\hline & & Chemical Stabilization by Apatite \\
\hline & & Down-Well Bio-Reactor/Adsorption Systems \\
\hline & & Nanotechnology \\
\hline DNAPLs & In Situ Treatment & Surfactant Flushing \\
\hline
\end{tabular}




\subsection{AREA DESCRIPTION}

The 200-PO-1 Groundwater OU is located in the 200 East Area of the Hanford Site as shown in Figure 2-1. The geographic boundaries of the 200-PO-1 Groundwater OU are the Columbia River to the east, the 300-FF-5 Groundwater OU to the south, and the 200-BP-5 Groundwater OU to the north. Groundwater in the unconfined aquifer generally flows north toward Gable Mountain in the northern 200 East Area, and southeasterly toward the Columbia River in the southern portion.

The 200-PO-1 Groundwater OU is separated into two main sections, the near field and far field, because of the amount of land the OU encompasses and the depth to groundwater in each section. The area near the sources of the plumes and closer to 200 East Area are the near field. This area is in the northwest corner of the OU. The far field is the area further away and more spread out to the south and to the east, stretching to the edges of the 200-PO-1 Groundwater OU. Near field plumes are generally higher in concentration with lower volume; far field plumes are generally more spread out with lower concentrations. The depth to groundwater in near field is about $91 \mathrm{~m}(300 \mathrm{ft})$ and the depth to groundwater in far field is around $30 \mathrm{~m}(100 \mathrm{ft})$. Figure 2-2 shows the layout of near field area of the 200-PO-1 Groundwater OU.

The contaminants of greatest concern in the OU groundwater are tritium, nitrate, and 1-129 (PNNL-15670, Hanford Site Groundwater Monitoring for Fiscal Year 2005). Strontium-90, Tc-99, uranium, cesium, and chromium are other contaminants that have been found in groundwater and will be part of this study. DNAPLs have not been found in the 200-PO-1 Groundwater OU, but are considered in the event of future discovery. 
Figure 2-1. Operable Units at Hanford Site and Far Field of the 200-PO-1 Groundwater Operable Unit.

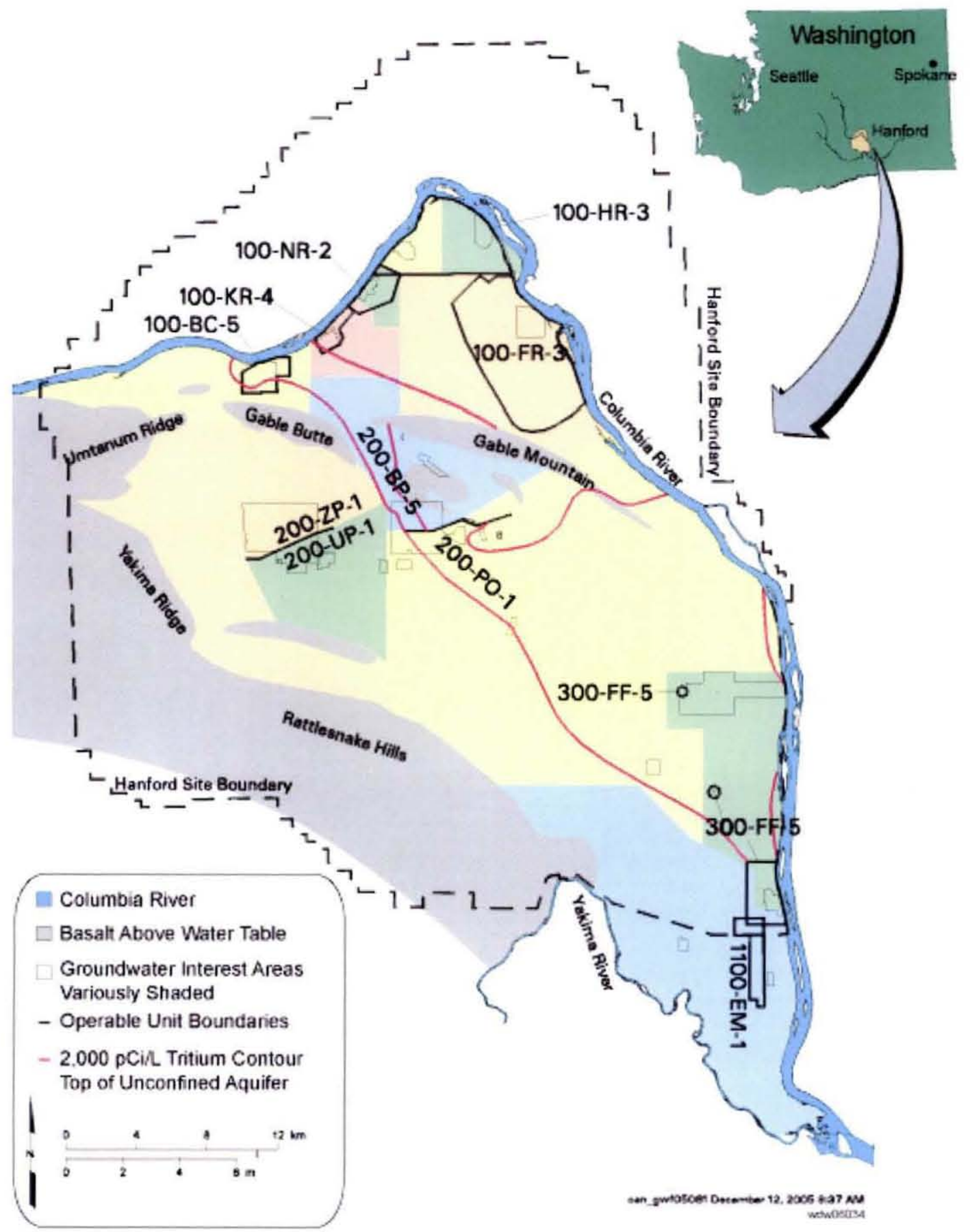


Figure 2-2. Near Field of the 200-PO-1 Groundwater Operable Unit.

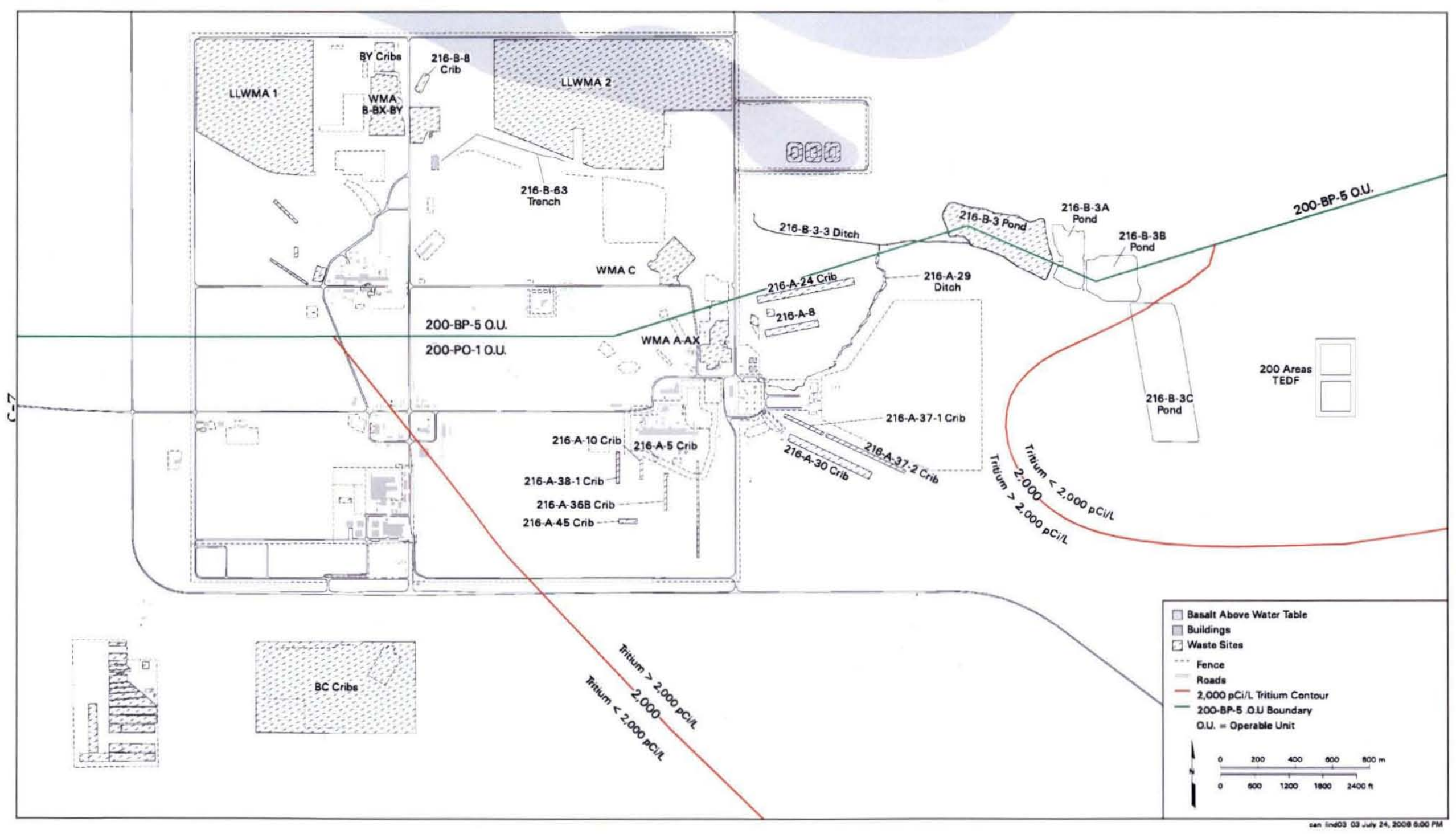


SGW-34562 REV 0

This page intentionally left blank. 


\subsection{FIRST STEP: TECHNOLOGIES NO LONGER CONSIDERED BASED ON PHYSICAL LIMITATIONS}

The first step is to eliminate technologies that are impractical for the 200-PO-1 Groundwater OU because of the environment, such as soil type or groundwater depth. Many technologies are unavailable for use at the 200-PO-1 Groundwater OU because of the depth to groundwater. Technologies are not screened out based on the plume size because of the various sizes for different COPCs at 200-PO-1 Groundwater OU, as described in Chapter 2.

\subsection{PHYSICAL CONTAINMENT}

Physical containment is a system of subsurface barriers consisting of vertically excavated trenches filled with slurry. The slurry, usually a mixture of bentonite clay and water, hydraulically shores the trench to prevent collapse and retards groundwater flow (FRTR, 2002). Two types of injection technology exist: grout walls (curtains) and freeze walls. These walls are injected into the ground using pre-drilled holes. Multiple holes close together are drilled to create a continuous layer of mixture (PNNL-15954).

Containment measures are often performed to prevent or significantly reduce the migration of contaminants in soils or groundwater. Containment is frequently used when contaminated materials are to be buried or left in place at a site. In general, containment is performed when extensive subsurface contamination at a site precludes excavation and removal of wastes because of potential hazards and/or unrealistic cost (FRTR, 2002).

The main advantage of containment methods is that they can prevent further migration of contaminant plumes and allow for contaminant reduction at sites where the source is undetermined, inaccessible, or where long term remedial actions are being developed. Unlike ex situ treatment groups, containment does not require excavation of contaminated soils, which leads to increased costs from engineering design of equipment, possible permitting, and material handling. However, containment methods do require periodic inspections for leaks, formation of liquid ponds, and corrosion, problems which are common among this type of technology.

Additionally, groundwater monitoring wells, associated with the containment method, need to be periodically sampled and monitored.

The problem with most physical containment technologies is that they are not suitable for use in aquifers like those in 200-PO-1 Groundwater OU, which are deeper than $24.4 \mathrm{~m} \mathrm{(80} \mathrm{ft).} \mathrm{Grout}$ curtains and slurry walls lose their vertical consistency past $30 \mathrm{~m}(100 \mathrm{ft})$ below ground surface (PNNL-15954). The depth to groundwater in the 200-PO-1 Groundwater OU generally ranges from 30.5 to $91.4 \mathrm{~m}$ (100 to $300 \mathrm{ft}$ ) below ground surface. Some depths decrease near the river, however, with more focus on source remediation and near field remediation, technologies such as physical containment should only be considered if more intensive study is needed on remediation closer to the river. Physical containment is not currently a feasible alternative for the 200-PO-1 Groundwater OU.

\subsection{REMOVAL, TREATMENT, AND DISPOSAL}

Removing the contaminated soil or groundwater is a general term for excavating the material using physical methods, such as removing the soil from the ground. The contaminated material is treated using an ex situ technique, such as a filter system. Then the leftover material and the 
removed contaminants are disposed to a predetermined location. This method may not be a final solution to the problem, but a means of relocating the contaminants. Also, the hole dug out from excavation must be filled. Either the cleaned dirt or fresh, clean dirt must be used.

This method is not a feasible alternative. The technologies applicable to removal, treatment, and disposal are targeted only at shallow (depth to groundwater less than $24.4 \mathrm{~m}$ [80 ft]) contamination (PNNL-15954). It is not applicable to the groundwater contamination at the 200-PO-1 Groundwater OU, which requires deeper groundwater remediation (depth to

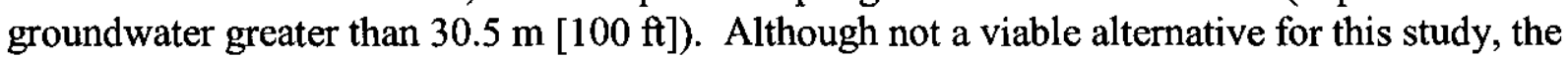
200-PO-1 Groundwater OU may contain locations of much shallower groundwater or a need for remediation of relatively shallow soil where removal, treatment, and disposal would be an alternative.

Table 3-1 summarizes the reasons why the above technologies are no longer considered based on the initial screening.

Table 3-1. Technologies Eliminated in Initial Screening.

\begin{tabular}{|c|l|}
\hline Technology & \multicolumn{1}{|c|}{ Reason } \\
\hline Physical Containment & $\begin{array}{l}\text { The groundwater depths at } 200-\mathrm{PO}-1 \text { Groundwater Operable Unit generally range } \\
\text { from } 30.5 \text { to } 91.4 \mathrm{~m}(100 \text { to } 300 \mathrm{ft}) \text { below ground surface in the near field. The } \\
\text { far field depth to groundwater is close to } 30.5 \mathrm{~m}(100 \mathrm{ft}) \text {. The depth to } \\
\text { groundwater decreases closer to the river. Physical containment technologies are } \\
\text { generally applicable to depths no greater than } 24.4 \mathrm{~m}(80 \mathrm{ft}) \text {. Starting at } 30.5 \mathrm{~m} \\
(100 \mathrm{ft}), \text { the effectiveness of the slurry wall or grout curtain greatly decreases. } \\
\text { Based on this depth constraint, physical containment is not considered for further } \\
\text { evaluation. }\end{array}$ \\
\hline $\begin{array}{c}\text { Removal, Treatment, and } \\
\text { Disposal }\end{array}$ & $\begin{array}{l}\text { Removing the groundwater at depths of over } 24.4 \mathrm{~m}(80 \mathrm{ft}) \text { is not feasible. The } \\
\text { applicability of removal, treatment, and disposal is to depths of less than } 24.4 \mathrm{~m} \\
\text { (80 ft). Treating groundwater above ground can be done through pump and treat } \\
\text { systems, but excavation is generally left for soil and shallow groundwater depths. }\end{array}$ \\
\hline
\end{tabular}




\subsection{SECOND STEP: EVALUATION OF TECHNOLOGIES}

The purpose of the second step of this study is to examine each remaining technology, and based on sources found, determine if the technology should be considered for remediation at the 200-PO-1 Groundwater OU. Each technology or method is screened using the evaluation criteria (Table 4-1) prior to examination of any of the technologies.

Table 4-1. Evaluation Criteria Used in Second Step of Screening.

\begin{tabular}{|l|l|}
\hline \multicolumn{1}{|c|}{ Evaluation Criteria Used In Second Step Of Screening } \\
\hline Tested & Has the technology been tested in the lab or in the field? \\
\hline Developed & How has the technology been used? Has it been a part of a remediation project? \\
\hline Implementability & $\begin{array}{l}\text { Is the technology effective for its intended purpose? Has it proven to be reliable? Can it } \\
\text { control the contaminants without negative impacts? } \\
\text { are the risks involved with the technology? }\end{array}$ \\
\hline Cost & $\begin{array}{l}\text { What are the main cost considerations for the technology? What factors would cause cost } \\
\text { variance at the 200-PO-1 Groundwater Operable Unit? }\end{array}$ \\
\hline Time & $\begin{array}{l}\text { How long does it take for the technology to be effective? Is the timeframe required for the } \\
\text { technology adequate for meeting remediation goals? }\end{array}$ \\
\hline
\end{tabular}

\subsection{PHYTOREMEDIATION}

Phytoremediation is a method that uses plants to remove, transfer, stabilize, and destroy organic contamination in groundwater. Much of the research is involved with the applicability of phytoremediation. The purpose of the research is to determine which contaminants can be effectively remediated by phytoremediation technologies. Currently, the known uses for phytotechnologies involve remediation of organic compounds, heavy metals (e.g., chromium, cesium), and strontium. Phytoremediation is not known to remediate other radionuclides, but it could be applicable to nitrate. There are several ways to use plants for phytoremediation. These mechanisms include enhanced rhizosphere biodegradation, hydraulic control, phyto-degradation, and phyto-volatilization. The phytoremediation information in this section was taken from FRTR, 2002.

\subsubsection{Enhanced Rhizosphere Biodegradation}

Enhanced rhizosphere biodegradation takes place in the soil surrounding plant roots. Natural substances released by plant roots supply nutrients to microorganisms, which enhances their ability to biodegrade organic contaminants. Plant roots also loosen the soil and then die, leaving paths for transport of water and aeration. This process tends to pull water to the surface zone and dry the lower saturated zones. 


\section{SGW-34562 REV 0}

\subsubsection{Hydraulic Control}

Depending on the climate, season, and type, trees can act as organic pumps when their roots reach down towards the water table and establish a dense root mass that take up large quantities of water.

\subsubsection{Phyto-Degradation}

Phyto-degradation is the metabolizing of contaminants within plant tissues. Plants produce enzymes, such as dehalogenase and oxygenase, which help catalyze degradation. Investigations are proceeding to determine if both aromatic and chlorinated aliphatic compounds are amenable to phyto-degradation.

\subsubsection{Phyto-Volatilization}

Phyto-volatilization occurs as plants take up water containing organic contaminants and release the contaminants into the air through their leaves. Plants also can break down organic contaminants and release breakdown products into air through leaves.

\subsubsection{Phytoremediation Studies}

Phytoremediation is limited to shallow soils, streams, and groundwater since high concentrations of hazardous materials can be toxic to plants. Climatic or seasonal conditions may interfere or inhibit plant growth, slow remediation efforts, or increase the length of the treatment period. It can transfer contamination across media (e.g., from soil to air). It is not effective for strongly sorbed (e.g., polychlorinated biphenyls) and weakly sorbed contaminants. Phytoremediation will likely require a large surface area of land. The toxicity and bioavailability of biodegradation products is not always known. Products may be mobilized into groundwater or bioaccumulated in animals. More research is needed to determine the fate of various compounds in the plant metabolic cycle to ensure that plant droppings and products manufactured by plants do not contribute toxic or harmful chemicals into the food chain or increase risk exposure to the general public.

In Iowa, the U.S. Environmental Protection Agency (EPA) demonstrated the use of phytoremediation by planting poplar trees along a stream bank between a cornfield and the stream. These trees acted as natural pumps to keep toxic herbicides, pesticides, and fertilizers out of the streams and groundwater. After three years, the nitrate concentration in groundwater at the edge of the cornfield was $150 \mathrm{mg} / \mathrm{L}$; the groundwater among the poplar trees along the stream bank had nitrate concentration of $3 \mathrm{mg} / \mathrm{L}$.

In the 100-N Area on the Hanford Site, a test using phytoremediation technology along the Columbia River Riparian Zone is being conducted. It is part of a treatment train in conjunction with an apatite injection system and monitored natural attenuation (MNA). This type of phytoremediation uses coyote willow trees to capture the Sr-90. Preliminary conclusions are that the coyote willows do remove $\mathrm{Sr}-90$ from the groundwater, suggesting this is a viable option for consideration in the far field portions of 200-PO-1 Groundwater OU.

Construction estimates for phytoremediation are $\$ 200 \mathrm{~K} /$ acre and $\$ 20 \mathrm{~K} /$ acre for operations and maintenance. Since phytoremediation is mostly available to shallow mediums (less than $30.5 \mathrm{~m}$ [100 ft] to groundwater) (PNNL-15954), it will be considered only for far field remediation close to the river. Table 4-2 shows the summary of evaluation for phytoremediation. 
SGW-34562 REV 0

Table 4-2. Phytoremediation.

\begin{tabular}{|c|l|}
\hline Evaluation Criteria & \multicolumn{1}{|c|}{ Monitored Natural Attenuation } \\
\hline Tested/Developed & $\begin{array}{l}\text { Phytoremediation has been tested and developed. The use of phytotechnology has been } \\
\text { used in full-scale remediation projects. }\end{array}$ \\
\hline Effectiveness & $\begin{array}{l}\text { The effectiveness of phytoremediation is known to be successful at remediating nitrate, } \\
\text { trichloroethylene, and other types of organic compounds. The effectiveness for nitrate is } \\
\text { promising because of the existence and concern of nitrate at the 200-PO-1 Groundwater } \\
\text { Operable Unit. }\end{array}$ \\
\hline Cost & $\begin{array}{l}\text { The required area for implementing a phytotechnology is large. Also, the time and effort } \\
\text { involved in the planting of trees and other phytotechnologies could be extensive. }\end{array}$ \\
\hline Time & $\begin{array}{l}\text { The size of the area involved is the main cost driver. This is an important consideration } \\
\text { because of the extensive area in the far field of the 200-PO-1 Groundwater Operable } \\
\text { Unit. Also, the tree maturity (size) is a factor. Implementing phytoremediation at a large } \\
\text { site such as the 200-PO-1 Groundwater Operable Unit could cost up to } \$ 0.64 \text { per square } \\
\text { foot. }\end{array}$ \\
\hline $\begin{array}{l}\text { The time involved for installing this technology could be great. Trees take time to plant } \\
\text { and grow; the longer the trees need to mature, the longer it takes for the technology to be } \\
\text { effective. }\end{array}$
\end{tabular}

\subsection{PERMEABLE REACTIVE BARRIERS}

Permeable reactive barrier (PRB) technology is a method of treating contaminated groundwater as it flows past a certain zone (PNNL-15954). The plume location and groundwater flow paths must be well known, so the PRB can be properly placed. It is a method of injecting a chemical or biological material into the ground to force the flow of groundwater to treat contamination. Some PRB types are zero-valent iron, adsorbent barriers, apatite by trenching, and multi-zone barriers. These PRBs are effective at remediating metals (such as chromium) and organic compounds (such as nitrate or trichloroethylene). They are not as effective at remediating 1-129 or tritium.

PRBs can be installed as permanent or semi-permanent units. The most commonly used PRB configuration is that of a continuous trench in which the treatment material is backfilled. The trench is perpendicular to and intersects the ground-water plume. Another frequently used configuration is the funnel and gate, in which low-permeability walls (the funnel) direct the ground-water plume toward a permeable treatment zone (the gate). Some gates are in situ reactors that are readily accessible to facilitate the removal and replacement of reactive media. These PRBs use collection trenches, funnels, or complete containment to capture the plume and pass the ground water, by gravity or hydraulic head, through a vessel containing either a single treatment medium or sequential media. In circumstances where in situ treatment is found to be impracticable, reactive vessels have been located above ground. (EPA, 2008)

A certain kind of PRB, in situ redox manipulation (ISRM), is the injection of a reducing solution, (usually sodium dithionite), which reacts with the contaminated medium and treats the contaminants. An ISRM barrier has been tested at the Hanford Site, and results are still being obtained. The effectiveness and implementability of ISRM barriers is promising. The depths at the 200-PO-1 Groundwater OU do present an issue, but only in the near field. PRBs in the far field are a good possible alternative where depths are only $30.5 \mathrm{~m}(100 \mathrm{ft})$. ISRM barriers continue to be examined for remediation. PRBs should be considered for far field remediation as part of the entire remediation project. Table 4-3 outlines the evaluation for PRBs. 
Table 4-3. Permeable Reactive Barriers.

\begin{tabular}{|c|l|}
\hline Evaluation Criteria & \multicolumn{1}{|c|}{ Permeable Reactive Barriers } \\
\hline Tested/Developed & $\begin{array}{l}\text { PRBs have been fully tested and implemented at sites around the nation, including the } \\
\text { Hanford Site. An ISRM barrier has been controlling contaminated groundwater flow and } \\
\text { treating contaminants in the 100-D Area of the 100-HR-3 Groundwater OU at the Hanford } \\
\text { Site. Constant monitoring is in place to determine if the technology has been successful or } \\
\text { not. }\end{array}$ \\
\hline Effectiveness & $\begin{array}{l}\text { The ISRM barrier has been successful, but the time frame has not met the original } \\
\text { expectation. The injected material must be reinjected because deterioration occurs faster } \\
\text { than expected. However, PRBs are generally successful at controlling smaller volumes of } \\
\text { contaminated groundwater. }\end{array}$ \\
\hline Implementability & $\begin{array}{l}\text { Installing a barrier big enough to control groundwater flow at the 200-PO-1 Groundwater } \\
\text { Operable Unit would be extensive because of the amount of material and land needed for } \\
\text { installation. A large number of wells would be required, as demonstrated in the current } \\
\text { Hanford Site ISRM barrier. }\end{array}$ \\
\hline Cost & $\begin{array}{l}\text { The quantity of material and the width of the plume are the main cost factors, which } \\
\text { increases significantly with larger plumes. Also, monitoring costs are a consideration. } \\
\text { Costs for a large plume size could be } \$ 1,961 \text { per cubic yard of treatment wall and } \$ 0.13 \text { for } \\
\text { cubic yard of groundwater treated. }\end{array}$ \\
\hline ISRM = in situ redox manipulation. \\
$=$ preliminary remediation goal. \\
gime depends on the size of the barrier, but expected treatment times are acceptable for \\
\hline
\end{tabular}

\subsection{MONITORED NATURAL ATTENUATION}

MNA is a natural process relying on physical or chemical reactions or radioactive decay to remediate contaminated groundwater. This process occurs without human intervention, but is monitored closely to determine the success of remediation.

MNA is a strong consideration for all COPCs. Some radionuclides naturally decay within a reasonable time. Tritium's half-life is 12 years, which makes it a likely constituent for MNA. The MNA process should eliminate human intervention to remediate the contaminants of the groundwater, since it is fully contained underground. MNA is an important process in any remediation project because it includes monitoring the groundwater. MNA has the potential to significantly reduce contamination concentrations and plume migrations of multiple contaminants. Not all contaminants naturally attenuate.

Besides radioactive decay, EPA, 2007 lists four other feasible MNA methods.

1. Tiny bugs or microbes that live in soil and groundwater use some chemicals for food. When they completely digest the chemicals, they can change them into water and harmless gases.

2. Chemicals can stick or sorb to soil, which holds them in place. This does not clean up the chemicals, but it can keep them from polluting groundwater and leaving the site.

3. As pollution moves through soil and groundwater, it can mix with clean water. This reduces or dilutes the pollution. 
4. Some chemicals, like oil and solvents, can evaporate, which means they change from liquids to gases within the soil. If these gases escape to the air at the ground surface, sunlight may destroy them.

MNA works best where the source of pollution has been removed. For instance, buried waste must be dug up and disposed of properly. Or it can be removed using other available cleanup methods. After the source is removed, the natural processes get rid of the small amount of pollution that remains in the soil and groundwater. The soil and groundwater are monitored regularly to make sure they are cleaned up. (EPA, 2007)

At the 200-PO-1 Groundwater OU, the source remediation decisions have not been made. However, current investigations are underway to determine the correct measures to take for source remediation. MNA should be considered, even though the sources have not yet been remediated, because of its effectiveness, implementability, cost, and time (Table 4-4).

Table 4-4. Monitored Natural Attenuation.

\begin{tabular}{|c|l|}
\hline Evaluation Criteria & \multicolumn{1}{|c|}{ Monitored Natural Attenuation } \\
\hline Tested/Developed & $\begin{array}{l}\text { MNA does not require testing since it is already in use at over 45 sites. It has been in use } \\
\text { by monitoring contaminant sources and plumes, wells, and other ways to sample } \\
\text { contaminated mediums. }\end{array}$ \\
\hline Effectiveness & $\begin{array}{l}\text { MNA can be effective for remediating all contaminants, specifically tritium (as it naturally } \\
\text { attenuates). MNA would not result in any byproducts or negative impacts, and is } \\
\text { independent of volume. }\end{array}$ \\
\hline Implementability & $\begin{array}{l}\text { MNA should be considered for tritium because it has no construction problems and little } \\
\text { concern for long-term risks. As long as MNA limits the plume migration, monitoring may } \\
\text { continue. }\end{array}$ \\
\hline Cost & $\begin{array}{l}\text { The costs for MNA are determined by initial evaluations and monitoring costs. Also, } \\
\text { strong cost drivers are the continued determinations of the success of the attenuation. }\end{array}$ \\
\hline Time & $\begin{array}{l}\text { Generally, MNA evaluations are done for at least a few years. Some constituents take } \\
\text { many years to decay, however, some, such as tritium, have more reasonable half-lives. }\end{array}$ \\
\hline
\end{tabular}

MNA = monitored natural attenuation.

\subsection{PUMP AND TREAT}

Pump and treat technology is a system in which groundwater is pumped above ground level and treated by some other technology or method to remediate the contaminated groundwater. The removed contaminants are disposed to a predetermined location and the treated groundwater is returned to its origin in the ground aquifer.

Pump and treat is a general method used for remediation of contaminated groundwater. Different types of pump and treat systems exist, such as bioreactors, adsorption systems, air stripping, granulated activated carbon, ion exchange, precipitation, coagulation, flocculation, and separation (FRTR, 2002). Precipitation, coagulation, and flocculation technologies are applicable to radionuclides (such as I-129 and tritium) and heavy metals (such as chromium, cesium), and strontium.

Currently, the Hanford Site has implemented pump and treat systems that utilize air stripping and activated carbon to remediate carbon tetrachloride and trichloroethylene. This process works well 
for those contaminants, but not necessarily for the COPCs for the 200-PO-1 Groundwater OU. Unless carbon tetrachloride or trichloroethylene is found to be a contaminant of concern, air stripping with activated carbon is not a good alternative for the 200-PO-1 Groundwater OU. The air stripping system using granulated activated carbon, such as the one in use at the 200-ZP-1 Groundwater OU to treat carbon tetrachloride, is working well. The system reduces contaminated groundwater from over $2,500 \mathrm{mg} / \mathrm{L}$ to $3 \mathrm{mg} / \mathrm{L}$.

Precipitation is used mainly to convert dissolved ionic species into solid-phase particulates that can be removed from the aqueous phase by coagulation and filtration (FRTR, 2002). Remedial application of this technology usually involves removal of dissolved toxic metals and radionuclides.

Pump and treat systems are in place at the 100 Areas and an electrocoagulation treatability study is being completed. The groundwater is pumped out and treated through electrocoagulation, where electric current is passed through to dissolve the iron in the contaminated water. The chromium is reduced from hexavalent chromium to trivalent chromium, which is the remediation objective. Current pump and treat systems in place at Hanford use an ion exchange resin to remove the hexavalent chromium. These pump and treat systems provide information and data that can be analyzed for implementation of a pump and treat system in the 200-PO-1 Groundwater OU.

Pump and treat systems, while they have been used for over twenty years, do have limitations and problems. The potential for long treatment time is high, sometimes over ten years for remediation of groundwater. The costs vary by site and system.

Pump and treat systems should be included for more intensive consideration for remediation at the 200-PO-1 Groundwater OU. There are multiple alternatives for pump and treat systems, with new technologies being studied and implemented, including at the Hanford Site. Table 4-5 presents the pump and treat evaluation summary.

Table 4-5. Pump and Treat.

\begin{tabular}{|l|l|}
\hline Evaluation Criteria & \multicolumn{1}{c|}{ Pump and Treat } \\
\hline Tested/Developed & $\begin{array}{l}\text { Pump and treat systems have been in place for a long time. Many pump and treat systems } \\
\text { currently are being used for site remediation, including systems at the Hanford Site. }\end{array}$ \\
\hline Effectiveness & $\begin{array}{l}\text { Pump and treat systems are effective at remediating the contaminated groundwater. With } \\
\text { use of zero-valent iron, or other methods, pump and treat systems have the ability to treat } \\
\text { the necessary contamination volume and contaminants of concern. }\end{array}$ \\
\hline Implementability & $\begin{array}{l}\text { Operation and maintenance are necessary for use of pump and treat systems, but because of } \\
\text { a vast number of systems in place, much is known about pump and treat systems and the } \\
\text { technology is not complicated. Pump and treat systems are widely available. }\end{array}$ \\
\hline Cost & $\begin{array}{l}\text { The main cost considerations for a pump and treat system are the number of wells necessary } \\
\text { for drilling, the volume of contamination for treatment, and the materials cost for the treating } \\
\text { systems. These vary depending on the type of pump and treat system. For precipitation and } \\
\text { coagulation systems, the main cost factors are design flow rate determinations. Capital costs } \\
\text { could be over } \$ 100,000 \text { with operating costs up to } \$ 0.18 \text { per } 1,000 \text { L. }\end{array}$ \\
\hline Time & $\begin{array}{l}\text { Pump and treat systems generally take a long time to remediate the necessary contaminant } \\
\text { volume, but with emerging technologies and innovations, the treatment time will be reduced. }\end{array}$ \\
\hline
\end{tabular}




\subsection{CHEMICAL STABILIZATION BY INJECTABLE APATITE}

This method injects liquid apatite into the aquifer to treat the entire volume of groundwater. Apatite solution (hydroxyapatite) can be effective in remediating heavy metals and radionuclides. The hydroxyapatite solution reacts with the heavy metals to precipitate and immobilize them (PNNL-15954). Apatite stabilization is effective on chromium, Tc-99, tritium, and I-129 in groundwater and can be considered for remediation for all COPCs in Group 1 and tritium. An alternative way to use this method is to inject the apatite into a PRB.

At the 100-N Area of Hanford Site, a pump and treat system using an injectable apatite is being tested. The injectable apatite at the Hanford Site is a PRB. The groundwater flows through the barrier and is remediated by the apatite mixture. Injectable apatite can be effective for remediating Group 1 groundwater contamination. The extent of effective area remediated by an injectable apatite barrier is about 5 acres. Table 4-6 shows the analysis for injectable apatite.

Table 4-6. Injectable Apatite.

\begin{tabular}{|l|l|}
\hline Evaluation Criteria & \multicolumn{1}{|c|}{ Chemical Stabilization by Injectable Apatite } \\
\hline Tested/Developed & $\begin{array}{l}\text { This technique is currently being tested for application to strontium contamination at } \\
\text { the 100-N Area of Hanford Site. Other tests have been done, but the technology is still } \\
\text { in the developmental stages. }\end{array}$ \\
\hline Effectiveness & $\begin{array}{l}\text { So far, the effectiveness for uranium has been very promising. The laboratory scale } \\
\text { studies have treated small amounts of contaminant volumes. With little or no } \\
\text { hazardous byproducts and minimal risks to the environment, this technique is generally } \\
\text { effective. }\end{array}$ \\
\hline Implementability & $\begin{array}{l}\text { Risks from construction and small range of treatment are current issues. Since } \\
\text { injectable apatite method is an innovative technology still under development, the } \\
\text { implementability is basically nothing right now. It is not feasible for installation in the } \\
\text { very near future, but continued testing may prove this technology to be effective } \\
\text { enough for implementation. }\end{array}$ \\
\hline Cost & $\begin{array}{l}\text { Costs for injectable apatite are dependant on the radius needed for remediation. A very } \\
\text { large radius may prove to be costly. }\end{array}$ \\
\hline Time & Currently, treatment time is unknown. \\
\hline
\end{tabular}

\subsection{CHEMICAL STABILIZATION BY POLYPHOSPHATE}

This method uses the technology of injecting liquid phosphate to stabilize uranium (PNNL-15954). Heavy metals and radionuclides can be remediated by polyphosphate technology; however, testing so far has been limited to uranium. Therefore, consideration of polyphosphate will be for uranium only.

The process uses polymers of phosphate to release phosphate at a slow, controlled rate into groundwater downgradient of the application point. The presence of phosphate in groundwater, even in minor concentrations $\left(10^{-8} \mathrm{M}\right)$, promotes the formation of autunite-group minerals, $\mathrm{X}_{3-\mathrm{n}}{ }^{(\mathrm{n})^{*}}\left[\left(\mathrm{UO}_{2}\right)\left(\mathrm{PO}_{4}\right)\right]_{2} \times \mathrm{H}_{2} \mathrm{O}$, thereby limiting the mobility of the uranyl cation ( $\mathrm{UO}_{2}{ }^{2+}$ ) in the subsurface environment. The use of soluble longchain polyphosphate reagent delays precipitation of the autunite, thereby mitigating 
plugging of the formation near the application point. By tailoring the polyphosphate chain, the hydrolysis reaction that releases the phosphate into the water can be engineered and the uranium stabilization rate controlled. Because autunite sequesters uranium in the oxidized form, $\mathrm{U}^{6+}$, rather than forcing reduction to $\mathrm{U}^{4+}$, the possibility of re-oxidation and subsequent re-mobilization is negated. Extensive laboratory testing demonstrates the very low solubility of autunite. In addition to autunite, excess phosphorous may result in apatite mineral formation, providing a secondary, long-term source of treatment capacity. (PNNL-15954)

A field-scale polyphosphate test is currently being done at the Hanford Site in the 300 Area. The polyphosphate test is to treat a uranium contaminated groundwater plume near the river. The field test will be done in support of the 300-FF-5 Groundwater OU feasibility study. The injection of the polyphosphate and the placement of the wells are all carefully planned. The injection of the polyphosphate is the latest step in the field test. Data from the test will help determine treatment options and will help with the final remediation decisions.

Because of extensive laboratory testing and the current test at the Hanford Site, this method may be applicable to uranium contamination. Development and testing of this technology will lead to more innovative treatment options and give lab results for uranium. It is a possible treatment method for uranium because of its effectiveness and implementability. Table 4-7 presents the evaluation summary for polyphosphate technology.

Table 4-7. Polyphosphate.

\begin{tabular}{|c|l|}
\hline Evaluation Criteria & \multicolumn{1}{|c|}{ Chemical Stabilization by Polyphosphate } \\
\hline Tested/Developed & $\begin{array}{l}\text { No field testing has been conducted. However, lab results are promising and have shown } \\
\text { that polyphosphate can reduce concentrations of uranium in small volumes. }\end{array}$ \\
\hline Effectiveness & $\begin{array}{l}\text { Has been shown to be effective for small volumes, more testing needed. No hazardous } \\
\text { byproducts or major risks to the ecological system or environment. }\end{array}$ \\
\hline Implementability & $\begin{array}{l}\text { Risks are involved for installation construction. More testing is needed to determine if } \\
\text { the distribution of polyphosphate is reliable. }\end{array}$ \\
\hline Cost & $\begin{array}{l}\text { Cost considerations are similar to those of the injectable apatite technology. The main } \\
\text { cost factor is the radius of influence to which the technology would be applied. }\end{array}$ \\
\hline Time & The time necessary for remediation is not known. \\
\hline
\end{tabular}

\subsection{DOWN-WELL BIOREACTOR SYSTEM}

A system implementing a down-well treatment system uses a bioreactor to treat contamination by placing the system in a borehole (PNNL-15954). This technology is used to treat I-129, tritium, chromium, uranium, and Tc-99. Its effectiveness on nitrate is minimal.

Contaminants in extracted ground water are put into contact with microorganisms in attached or suspended growth biological reactors. In suspended systems, such as activated sludge, contaminated ground water is circulated in an aeration basin. In attached systems, such as rotating biological contractors and trickling filters, microorganisms are established on an inert support matrix. (FRTR, 2002) 
Bioreactors have been lab tested, but not field tested on a larger scale. Bioreactors will be considered only as a possible remedy solution pending further studies and tests, and possibly a large scale field demonstration. Table 4-8 shows the evaluation for bioreactor systems.

Table 4-8. Bioreactor System.

\begin{tabular}{|c|l|}
\hline Evaluation Criteria & \multicolumn{1}{c|}{ Down-Well Bioreactor System } \\
\hline Tested/Developed & $\begin{array}{l}\text { Bioreactors have been developed and tested extensively, but only for groundwater } \\
\text { treatment during the past } 10 \text { years. More testing is still needed. }\end{array}$ \\
\hline Effectiveness & $\begin{array}{l}\text { No hazardous byproducts or negative impacts are expected, however, this could change } \\
\text { as more testing is completed. As not much is known, more testing is needed. Small } \\
\text { treatment areas have been remediated by bioreactors, but only in the lab. }\end{array}$ \\
\hline Implementability & $\begin{array}{l}\text { A lot of drilling and maintenance would be necessary for operation and use as a remedial } \\
\text { activity. Installation of the system would take time. }\end{array}$ \\
\hline Cost & $\begin{array}{l}\text { Costs significantly increase as the number of wells increases, which would occur to } \\
\text { accommodate small treatment areas. The main considerations for cost are based on the } \\
\text { specific contaminant and contaminant concentration. A single unit installation would } \\
\text { cost approximately } \$ 80,000 \text { and cover } 13,935 \mathrm{~m}^{2}\left(150,000 \mathrm{ft}^{2}\right) .\end{array}$ \\
\hline Time & $\begin{array}{l}\text { Treatment times are not fully known because of lack of testing in the field. It is } \\
\text { suggested that higher treatment times can be expected because this is a long term } \\
\text { treatment method. }\end{array}$ \\
\hline
\end{tabular}

\subsection{SURFACTANT FLUSHING}

Surfactant (surface-active-agents) flushing is a technology that uses a mixture (nonionic and anionic) to help immobilize or stabilize NAPL or DNAPL.

The surfactants function by lowering the NAPL-water interfacial tension and decreasing capillary forces within the porous media, which creates a microemulsion system and solubilizes the contaminant. In most demonstrations, surfactants or cosolvents are pumped through the aquifer displacing at least one or more pore volumes of groundwater, followed by several pore volumes of water to remove the residual surfactant. Various well configurations are used including single vertical circulation wells and injection/extraction well networks. Recovered contaminant with recovered surfactant is processed ex-situ using a variety of treatment processes. (PNNL-15954)

This process is applicable to carbon tetrachloride and DNAPLs if they are present. Other COPC groups are not currently affected by this technology. Also, only a small source area would be applicable for remediation. If DNAPLs are considered a concern in the future, entire studies will need to be done to characterize the contaminants and determine which methods of remediation would be applicable. Table 4-9 summarizes the evaluation of surfactant flushing. 
Table 4-9. Surfactant Flushing.

\begin{tabular}{|c|l|}
\hline Evaluation Criteria & \multicolumn{1}{|c|}{ Surfactant Flushing } \\
\hline Tested/Developed & $\begin{array}{l}\text { Surfactant flushing has been tested and used in remediation projects. It has shown } \\
\text { promise on the full scale. }\end{array}$ \\
\hline Effectiveness & $\begin{array}{l}\text { With DNAPL and carbon tetrachloride, surfactant flushing can be very effective to } \\
\text { remediate contaminant zones. Hazardous byproducts are not expected except for in } \\
\text { reductive dechlorination of carbon tetrachloride and trichloroethylene. Surfactant } \\
\text { flushing could also disperse other contaminants and is only applicable to a DNAPL area. }\end{array}$ \\
\hline Implementability & $\begin{array}{l}\text { The main risk would be from drilling. Problems are expected during separation of the } \\
\text { solvent at the end of the cycle. Based on rates of consumption by the surfactant, this } \\
\text { technology may not be feasible. }\end{array}$ \\
\hline Cost & $\begin{array}{l}\text { Main cost factors are well drilling and groundwater injection. To ensure the capture of } \\
\text { the mobilized contaminants, a great deal of groundwater recirculation infrastructure is } \\
\text { needed. Also, costs for surfactants is to be considered. }\end{array}$ \\
\hline Time & Treatment times are expected to be very high. \\
\hline
\end{tabular}

DNAPL $=$ dense, nonaqueous-phase liquid.

\subsection{ANAEROBIC BIOREMEDIATION}

Anaerobic bioremediation can reduce contaminants from all groups to non-hazardous products or insoluble forms. Anaerobic bioremediation can convert nitrate to a safe material and it can convert chromium, Tc-99, and uranium to insoluble forms (PNNL-15954). Also, it can adsorb other contaminants, such as I-129. It relies on the distribution of substrate and activity of appropriate bacteria already present in the soil. Remediation goals may not be met because of specific site geochemistry and microbial ecology. Site-specific evaluations and studies would need to be made prior to the final decision.

In situ anaerobic bioremediation could also be implemented by distributing a long-duration substrate such as vegetable oil into the aquifer. Because the substrate is less accessible to the bacteria, it is not consumed as it is distributed and can provide a long-term food supply once in place. The key property with this technology is the hydraulic conductivity of the aquifer. The radius of the treatment zone depends on how well the substrate can be injected into and distributed through the aquifer formation. A secondary property of interest is the length of time that the substrate lasts, which impacts the frequency of "regenerating" the treatment zone. The radius of influence for long-duration substrate injection will be less than that for a soluble substrate. Functionally, a radius of about $7 \mathrm{~m}$ for oil distribution is similar to what has been achieved for other applications of this technology. (PNNL-15954)

This method is extremely promising and is a possibility for all treatment groups, except tritium. It is effective, can be implemented, and has cost comparable to other technologies of the same functionality and influence. Table 4-10 details the bioremediation summary of evaluation. 
Table 4-10. Anaerobic Bioremediation.

\begin{tabular}{|c|l|}
\hline Evaluation Criteria & \multicolumn{1}{c|}{ Anaerobic Bioremediation } \\
\hline Tested/Developed & $\begin{array}{l}\text { Bioremediation has been tested and used in the field. It has proven successful and is } \\
\text { developed. Further testing will be done to demonstrate its wide range of effectiveness. }\end{array}$ \\
\hline Effectiveness & $\begin{array}{l}\text { May not remediate technetium-99 and uranium to cleanup goals, but it may be } \\
\text { extremely effective to fully stabilizing and immobilizing chromium in the contaminated } \\
\text { groundwater and may achieve increased absorption of iodine-129. Also, reduction of } \\
\text { nitrate to nitrogen gas is likely, making it useful for nitrate remediation. No hazardous } \\
\text { byproducts or negative impacts would be expected. Small or large contaminant volumes } \\
\text { are treatable by bioremediation, making it flexible for use on small concentrated plumes } \\
\text { or large spread out plumes. }\end{array}$ \\
\hline Implementability & $\begin{array}{l}\text { One issue with bioremediation is the use of wells. Each well would have a small radius } \\
\text { of influence, therefore, many wells would be needed for large plumes. This increases } \\
\text { installation costs and times, monitoring costs, and material costs. }\end{array}$ \\
\hline Cost & $\begin{array}{l}\text { The costs for bioremediation depend heavily on the number of wells. The amount of } \\
\text { material needed also depends on the number of wells. Typically, costs are about } \$ 40 \text { to } \\
\$ 80 \text { per l,000 gallons of groundwater treated. }\end{array}$ \\
\hline Time & $\begin{array}{l}\text { Time is also an important factor relying on the number of wells. It has not yet been } \\
\text { determined if treatment times are feasible for remediation. However, groundwater } \\
\text { treatment times are generally longer than other treatment options. }\end{array}$ \\
\hline
\end{tabular}

\subsection{NANOTECHNOLOGY}

Future site remediation will rely heavily on the development, testing, and implementation of new innovative technologies (Watlington, 2005, Emerging Nanotechnologies for Site Remediation and Wastewater Treatment). As people begin to think more about their impact on the environment, safer and cleaner methods of remediation and stricter remediation objectives will be required. This requirement will extend to site remediation. One way to assist in the development or testing of new technologies is to study new ways to clean up the waste at the Hanford Site. One possible technology in the near future is nanotechnology. Nanotechnology is a rapidly growing field, which has the opportunity to account for 14 percent of revenue from manufacturing in the U.S., an increase from 0.1 percent in 2004 (Harrison, 2007, Geo Year Book 2007: An Overview of Our Changing Environment).

Nanotechnology has the possibility to remediate any and all COPCs at the 200-PO-1 Groundwater OU. With nearly limitless research possibilities on nanotechnology in the future, diverse methods of using nanoparticles and nanotechnology for remediation are extremely probable. All contaminant groups will be considered for nanotechnology in the future.

Nanoparticles are roughly the size of 1 to 100 nanometers and can achieve properties that other materials cannot. These properties make nanoparticles a desirable option for applications in the near future. Nanotechnology is being studied for use in medicine, material manufacturing, energy production, detection and remediation of pollution, and other sectors. However, with all of the current studies, little is known about the negative impacts of using nanoparticles (Harrison, 2007). Without knowing long-term effects on the organisms and ecosystems, efforts cannot be exerted into using new nanotechnology for remediation at the Hanford Site. However, exploration of the idea of nanotechnology and one current remedial activity, zero-valent iron, may begin. 
Zero-valent iron nanotechnology has been tested more than most other nanotechnologies for remediation (CR-05-007ENV, Cost and Performance Report Nanoscale Zero-Valent Iron Technologies for Source Remediation). Around the nation and at the Hanford Site, pump and treat systems and PRBs have used zero-valent iron for remediation. Zero-valent iron can reduce hexavalent chromium to trivalent chromium, thus immobilizing the contaminant and allowing it to be precipitated out of the solution (Watlington, 2005).

Even though nanoscale zero-valent iron is promising, the technology still only applies to shallow aquifers and is still relatively more expensive than other technologies. But with the study of nanotechnology, new and innovative methods will be found and testing will be done to determine if nanotechnology can be used for future site remediation. The versatility of nanotechnology is high because of the small size of the particles. This is promising for the future, when the Hanford Site remediation has greater needs and requirements.

Because of the lack of information on the effects of nanotechnology for site remediation, it should be further considered in future studies, with more focus on emerging technologies and current lab research. This study focuses on remedial activities, and without full testing, nanotechnology will no longer be considered as an alternative. In Table 4-11, the summary of evaluation shows the criteria for determining if nanotechnology can be beneficial.

Table 4-11. Nanotechnology.

\begin{tabular}{|c|l|}
\hline Evaluation Criteria & \multicolumn{1}{c|}{ Nanotechnology } \\
\hline Tested/Developed & $\begin{array}{l}\text { Nanotechnology is mostly in the development stage. Some forms of nanotechnology } \\
\text { have been tested, such as the pump and treat system utilizing zero-valent iron at the } \\
\text { Hanford Site. The results are promising and along with other systems being tested in the } \\
\text { lab and in the field, nanotechnology may be the future for site remediation. However, } \\
\text { many issues remain, such as long term effects of nanoparticles in the soil and } \\
\text { groundwater. }\end{array}$ \\
\hline Effectiveness & $\begin{array}{l}\text { The nanoparticle technology is being studied today and has been tested over the past ten } \\
\text { years. Some results show promise for reducing different contaminants or other remedial } \\
\text { purposes. Large scale tests have been done, including zero-valent iron, which was used } \\
\text { in permeable reactive barriers for groundwater treatment. Observations of reduced } \\
\text { contaminants have been confirmed, thus proving the method can be successful at } \\
\text { remediating groundwater. }\end{array}$ \\
\hline Implementability & $\begin{array}{l}\text { True nano-sized particles show the most promise, making the availability of the } \\
\text { technology much less because of costs of manufacturing nanoparticles. Long-term } \\
\text { monitoring would be needed also. }\end{array}$ \\
\hline Cost & $\begin{array}{l}\text { Costs of nanoscale technologies would be much greater as they are introduced than what } \\
\text { they may be if more sites implement nanotechnology. It is not possible to determine the } \\
\text { actual costs of any nanotechnology application at Hanford Site yet. }\end{array}$ \\
\hline $\begin{array}{l}\text { Treatment times are dependant on the size of the contaminated zone. As treatment time } \\
\text { increases, the effectiveness of the nanoparticles increases. }\end{array}$ \\
\hline
\end{tabular}




\subsection{CONCLUSIONS}

This study is to determine which technologies can be applied to remediation at the 200-PO-1 Groundwater OU at Hanford Site. The purpose is to suggest technologies that should be further considered for groundwater remediation. All technologies found applicable to 200-PO-1 Groundwater OU were screened among the same evaluation criteria. However, not all technologies are applicable to all COPCs at the 200-PO-1 Groundwater OU. Also, the way 200-PO-1 Groundwater OU is laid out presents two different types of targets for remediation. Near field remediation requires technologies applicable to small volumes of high concentration with the possibility of deep (over $30.5 \mathrm{~m}$ [100 ft]) aquifers. Far field remediation requires technologies applicable to large, spread out volumes of lower concentration at comparably shallower groundwater depths. Most technologies cannot be screened out based solely on plume size. The evaluation criteria took this into account, and the summary in Table 5-1 separates technologies by section and contaminant group.

Table 5-1. Summary of Technologies Suggested for Further Consideration.

\begin{tabular}{|c|c|c|c|c|}
\hline $\begin{array}{c}\text { Remediation } \\
\text { Target }\end{array}$ & $\begin{array}{l}\text { COPC Group } 1 \text { (Iodine-129, } \\
\text { Technetium-99, Strontium-90, } \\
\text { Chromium, Uranium, Cesium) }\end{array}$ & $\begin{array}{c}\text { COPC Group } 2 \\
\text { (nitrate) }\end{array}$ & $\begin{array}{c}\text { COPC Group } 3 \\
\text { (tritium) }\end{array}$ & DNAPLs \\
\hline $\begin{array}{l}\text { Near Field (High } \\
\text { Concentrations, } \\
\text { Low Volumes) }\end{array}$ & $\begin{array}{l}\text { - MNA } \\
\text { - } \text { Pump and Treat } \\
\text { - Stabilization by } \\
\text { Polyphosphate (uranium) } \\
\text { - Down-Well Bioreactor } \\
\text { System } \\
\text { - Anaerobic Bioremediation } \\
\text { - Nanotechnology }\end{array}$ & $\begin{array}{l}\text { - Phytoremediation } \\
\text { - MNA } \\
\text { - Pump and Treat } \\
\text { Aioremediation } \\
\text { (also as a PRB) } \\
\text { - ISRM as a PRB } \\
\text { - Nanotechnology }\end{array}$ & $\begin{array}{l}\text { - PRB } \\
\text { - MNA } \\
\text { - } \text { Pump and Treat } \\
\text { - Down-Wectable Apatite } \\
\text { Bioreactor System } \\
\text { - Nanotechnology }\end{array}$ & $\begin{array}{l}\text { Surfactant } \\
\text { Flushing }\end{array}$ \\
\hline $\begin{array}{l}\text { Far Field (Low } \\
\text { Concentrations, } \\
\text { High Volumes) }\end{array}$ & $\begin{array}{l}\text { - Phytoremediation (chromium, } \\
\text { cesium, strontium) } \\
\text { ISRM Barrier (PRB) for all } \\
\text { except iodine } \\
\text { - MNA } \\
\text { - Pump and Treat } \\
\text { - Down-Well Bioreactor } \\
\text { System } \\
\text { - Anaerobic Bioremediation as } \\
\text { a PRB } \\
\text { - ISRM as a PRB (except } \\
\text { iodine) } \\
\text { - Nanotechnology }\end{array}$ & $\begin{array}{l}\text { - Phytoremediation } \\
\text { - MNA } \\
\text { - Pump and Treat } \\
\text { - Anaerobic } \\
\text { Bioremediation as a } \\
\text { PRB } \\
\text { - ISRM as a PRB } \\
\text { - Nanotechnology }\end{array}$ & $\begin{array}{l}\text { - MNA } \\
\text { - Pump and Treat } \\
\text { - Nanotechnology }\end{array}$ & $\begin{array}{l}\text { Surfactant } \\
\text { Flushing }\end{array}$ \\
\hline $\begin{array}{ll}\text { COPC } & =\text { co } \\
\text { DNAPL } & =\text { de } \\
\text { ISRM } & =\text { in } \\
\text { MNA } & =\mathrm{m} \\
\text { PRB } & =\text { pe }\end{array}$ & $\begin{array}{l}\text { taminant of potential concern. } \\
\text { ise, nonaqueous-phase liquid. } \\
\text { situ redox manipulation. } \\
\text { nitored natural attenuation. } \\
\text { meable reactive barrier. }\end{array}$ & & & \\
\hline
\end{tabular}


Technologies ready for implementation and technologies that require more testing and research need to be considered for the 200-PO-1 Groundwater OU. Table 5-2 shows the conclusions based on current implementability of the technologies.

Table 5-2. Summary of Current Implementability of Technologies.

\begin{tabular}{|c|c|c|c|c|}
\hline Implementability & COPC Group 1 & COPC Group 2 & COPC Group 3 & DNAPLs \\
\hline $\begin{array}{l}\text { Implementable now, with } \\
\text { minimal tailoring to suit } \\
200-P O-1 \text { Groundwater } \\
\text { OU COPC's and } \\
\text { conditions }\end{array}$ & $\begin{array}{l}\text { - Phytoremediation } \\
\text { ISRM Barrier as } \\
\text { PRB, for all except } \\
\text { iodine } \\
\text { - MNA } \\
\text { - Pump and Treat } \\
\text { - Down-Well } \\
\text { Bioreactor System }\end{array}$ & $\begin{array}{l}\text { - Phytoremediation } \\
\text { - MNA } \\
\text { - Pump and Treat } \\
\text { - ISRM as a PRB }\end{array}$ & $\begin{array}{l}\text { - PRB } \\
\text { - MNA } \\
\text { - Pump and Treat } \\
\text { - Down-Well } \\
\text { Bioreactor System }\end{array}$ & None \\
\hline $\begin{array}{l}\text { Implementable pending } \\
\text { further studies, testing, } \\
\text { and investigation to } \\
\text { determine the } \\
\text { applicability at the } \\
200-P O-1 \text { Groundwater } \\
\text { OU }\end{array}$ & $\begin{array}{l}\text { - Injectable Apatite } \\
\text { - Stabilization by } \\
\text { Polyphosphate } \\
\text { - Anaerobic } \\
\text { Bioremediation } \\
\text { - Nanotechnology }\end{array}$ & $\begin{array}{l}\text { - Anaerobic } \\
\text { Bioremediation } \\
\text { - Nanotechnology }\end{array}$ & $\begin{array}{l}\text { - Injectable Apatite } \\
\text { - Nanotechnology }\end{array}$ & $\begin{array}{l}\text { - Surfactant } \\
\text { Flushing }\end{array}$ \\
\hline $\begin{array}{l}\text { COPC }=\text { contaminant } \\
\text { DNAPL }=\text { dense, nonac } \\
\text { ISRM }=\text { in situ redox } \\
\text { MNA }=\text { monitored na } \\
\text { OU }\end{array}$ & $\begin{array}{l}\text { of potential concern. } \\
\text { queous-phase liquid. } \\
\text { manipulation. } \\
\text { atural attenuation. } \\
\text { t. } \\
\text { active barrier. }\end{array}$ & & & \\
\hline
\end{tabular}




\subsection{REFERENCES}

CR-05-007ENV, 2005, Cost and Performance Report Nanoscale Zero-Valent Iron Technologies for Source Remediation, Naval Facilities Engineering Command, Port Hueneme,

California. Available online at http:/www.clu-in.org/download/remed/cr-05-007-env.pdf.

EPA, 1993, Guidance for Evaluating the Technical Impracticability of Ground-Water

Restoration, EPA Directive 9234.2-25, U. S. Environmental Protection Agency, Office of

Solid Waste and Emergency Response, Washington, D.C.

EPA, 2008, Hazardous Waste Clean-Up Information (CLU-IN), U.S. Environmental Protection

Agency, Washington D.C. Available online at http://www.cluin.org/remed1.cfm.

FRTR, 2002, Remediation Technologies Screening Matrix and Reference Guide, $4^{\text {th }}$ Edition, Federal Remediation Technology Roundtable, Washington D.C. Available online at http://www.frtr.gov/matrix 2/top page.html.

Harrison, P. (ed.), 2007, Geo Year Book 2007: An Overview of Our Changing Environment, Division of Early Warning and Assessment, United Nations Environment Program, Nairobi 00100 , Kenya. Available online at http://www.unep.org/geo/yearbook/yb2007.

PNNL-15670, 2006, Hanford Site Groundwater Monitoring for Fiscal Year 2005, Pacific Northwest National Laboratory, Richland, Washington.

PNNL-15954, 2006, Screening of Potential Remediation Methods for the 200-ZP-1 Operable Unit at the Hanford Site, Pacific Northwest National Laboratory, Richland, Washington.

PNNL-16346, 2007, Hanford Site Groundwater Monitoring for Fiscal Year 2006, Pacific Northwest National Laboratory, Richland, Washington.

Watlington, K., 2005, Emerging Nanotechnologies for Site Remediation and Wastewater Treatment, U.S. Environmental Protection Agency, Washington D.C. 
SGW-34562 REV 0

This page intentionally left blank.

6-2 


\section{DISTRIBUTION}

\section{Onsite}

U.S. Department of Energy

Richland Operations Office

DOE Public Reading Room

R. D. Hildebrand

(3)

$\mathrm{H} 2-53$

A6-38

22 Fluor Hanford, Inc.

M. W. Benecke

E6-44

M. E. Byrnes

E6-44

G. D. Cummins

E6-44

D. B. Erb*

E6-35

B. H. Ford*

E6-44

P. M. Gent*

E6-44

M. J. Hickey*

E6-44

M. J. Lindberg*

P7-22

S. P. Luttrell

E6-35

S. M. Narbutovskih

E6-44

R. W. Oldham

E6-35

S. L. Pedersen

(3)

E6-44

L. C. Swanson

E6-35

W. R. Thackaberry

E6-35

G. S. Thomas

E6-44

M. W. Vermillion*

$\mathrm{S} 0-02$

B. A. Williams

E6-44

J. A. Winterhalder*

E6-35

C. S. Wright

E6-35

Geosciences Library

E6-35

2

Environmental Quality Management

M. Miller

T. DiFibbo

2

Freestone Environmental Services

D. K. Tyler

S. P. Airhart

2

Lockheed Martin Services, Inc.

Document Processing Center

H6-08

Pacific Northwest National Laboratory

Hanford Technical Library

P8-55

Distr.-1 
SGW-34562 REV 0

This page intentionally left blank.

Distr.-2 